PRZEDSIĘBIORCZOŚĆ - EDUKACJA NR 1

KRAKÓW 2005

\author{
Edyta Osuch \\ XXX Liceum Ogólnokształcące, Kraków \\ Wiktor Osuch \\ Zakład Dydaktyki Geografii \\ Instytut Geografii \\ Akademia Pedagogiczna, Kraków
}

\title{
Przedmiot podstawy przedsiębiorczości w opinii uczniów i rodziców na przykładzie wybranych krakowskich szkół
}

Od 1 września 2002 r. do polskich szkół ponadgimnazjalnych został wprowadzony przedmiot podstawy przedsiębiorczości. Zgodnie z Rozporządzeniem Ministerstwa Edukacji Narodowej i Sportu z dnia 26 lutego 2002 r. dotyczącym podstawy programowej kształcenia ogólnego przedmiot ten ma na celu uczyć postaw przedsiębiorczych oraz przygotować młodych ludzi do aktywnego udziału w życiu społeczno-gospodarczym.

Przedmiot podstawy przedsiębiorczości pomaga zrozumieć młodemu człowiekowi mechanizmy funkcjonowania gospodarki wolnorynkowej. Ponadto kładzie duży nacisk na planowanie przyszłej kariery zawodowej, kształci umiejętności sprawnego komunikowania się oraz przygotowuje młodzież do planowania i realizacji przedsięwzięć w otaczającym go środowisku.

Niniejszy artykuł zawiera wyniki badań ankietowych przeprowadzonych wśród losowo wybranych uczniów i ich rodziców z trzech krakowskich szkół: Zespołu Szkół Ogólnokształcących Nr 14 - XXX Liceum Ogólnokształcące, Publicznego Salezjańskiego Liceum Ogólnokształcącego oraz V Liceum Ogólnokształcącego.

W badaniach zapytano uczniów i rodziców, czy wprowadzenie nowego przedmiotu do szkół ponadgimnazjalnych uważają za słuszny krok w polskiej edukacji (ryc. 1).

Ryc. 1. Opinie uczniów na temat słuszności wprowadzenia przedmiotu podstawy przedsiębiorczości do szkół ponadgimnazjalnych

Ryc. 1. Opinie uczniów na temat słuszności wprowadzenia przedmiotu podstawy przedsiębiorczości do szkół ponadgimnazjalnych
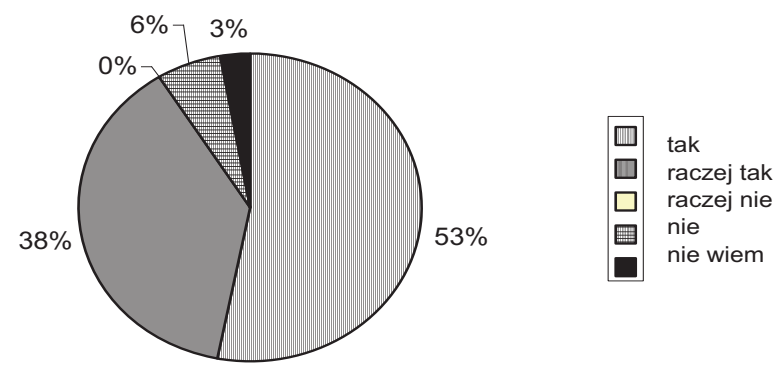
W sumie aż 91\% przebadanych licealistów uważa tą decyzję za słuszną, a tylko 6\% uczniów jest odmiennego zdania. Jeszcze lepiej wypadły badania wśród rodziców, którzy w 96,7\% uważają nowy przedmiot za potrzebny w cyklu kształcenia ich dzieci.

Interesujące wydają się wypowiedzi młodzieży dotyczące wykorzystania treści przekazywanych na lekcjach podstaw przedsiębiorczości w ich dalszym dorosłym życiu społeczno-gospodarczym (ryc. 2). Najbardziej o tym jest przekonana młodzież z Publicznego Salezjańskiego Liceum oraz z XXX Liceum Ogólnokształcącego. W sumie ponad 94\% ankietowanych uważa, że w przyszłości wykorzysta wiadomości i umiejętności zdobyte na lekcjach z podstaw przedsiębiorczości. Podobnego zdania jest zdecydowana większość rodziców $(97,3 \%)$.

Ryc. 2. Opinie uczniów na temat wykorzystania treści przekazywanych na lekcjach $\mathrm{z}$ podstaw przedsiebiorczości $\mathrm{w}$ przygotowaniu ich do dalszego życia społecznogospodarczego

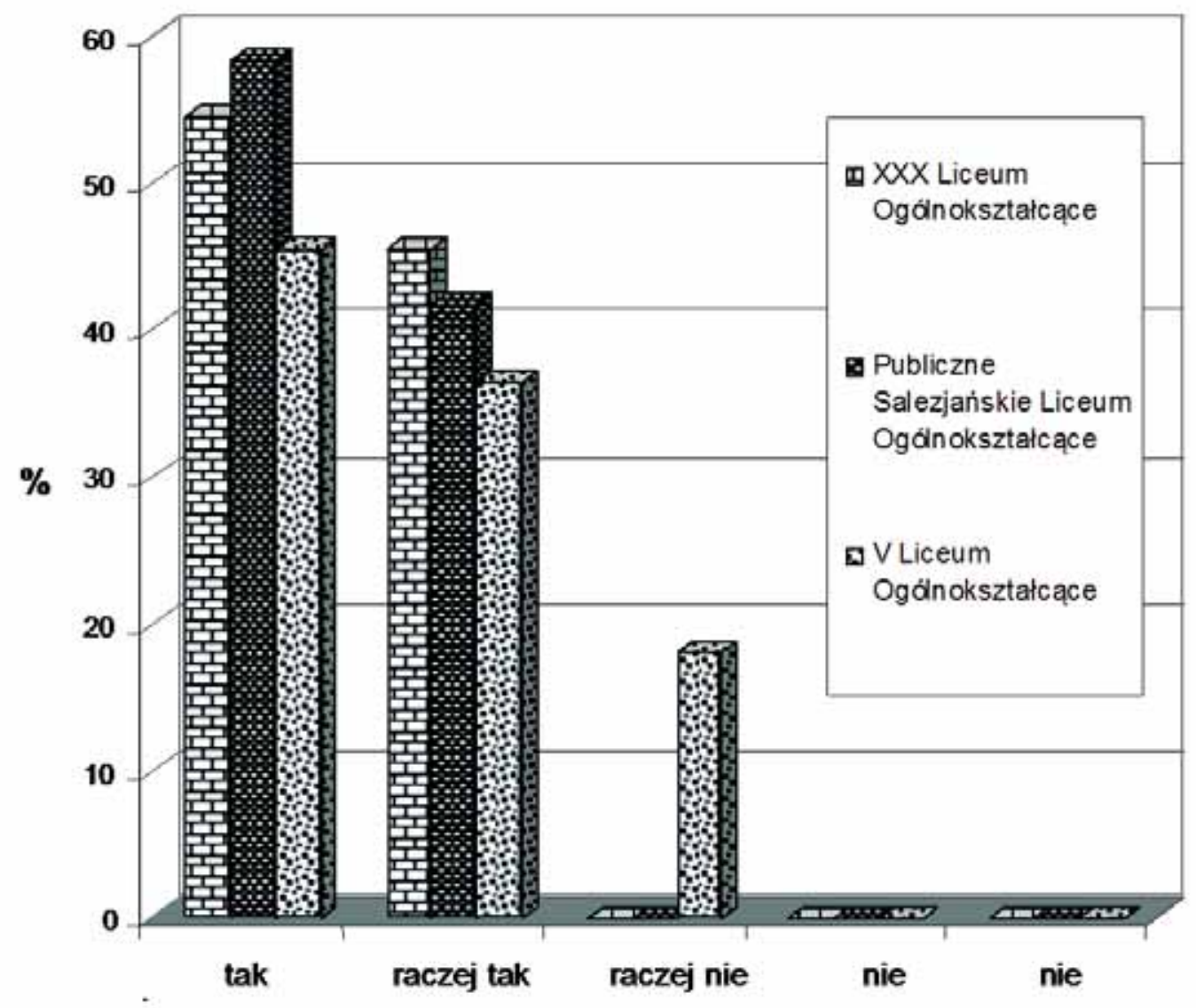

Zapytano również uczniów o najbardziej interesujące ich treści kształcenia, które ustalone zostały według działów tematycznych przyjętych z programu nauczania podstaw przedsiębiorczości autorstwa Zbigniewa Makieły i Tomasza Rachwała Wydawnictwa Nowa Era (2002) - ryc. 3.

Najwięcej ankietowanych uczniów interesuje się zagadnieniami dotyczącymi problematyki pracy, bankowości oraz podatków i ubezpieczeń. W kolejnych wypowiedziach podali bardziej szczegółowe treści kształcenia, którymi się szczególnie interesują:

- praca - szukanie i podejmowanie pracy; rozmowa kwalifikacyjna; praca w gospodarce rynkowej $-24,2 \%$; 
- zakładanie i prowadzenie własnej działalności gospodarczej - 22,6\%;

- $\quad$ komunikacja interpersonalna - negocjacje - asertywność - 14,5\%;

- podatki, rozliczenia PIT, ubezpieczenia - 14,5\%;

- pieniądz - zarządzanie pieniędzmi - bankowość - wybór banku - 12,9\%.

Ponadto badani licealiści wymienili zagadnienia dotyczące: budżetu państwa, giełdy, reklamy, polityki cen, czy orientacji w polskim systemie prawnym.

Ryc. 3. Najbardziej interesujące treści kształcenia w opinii uczniów i rodziców

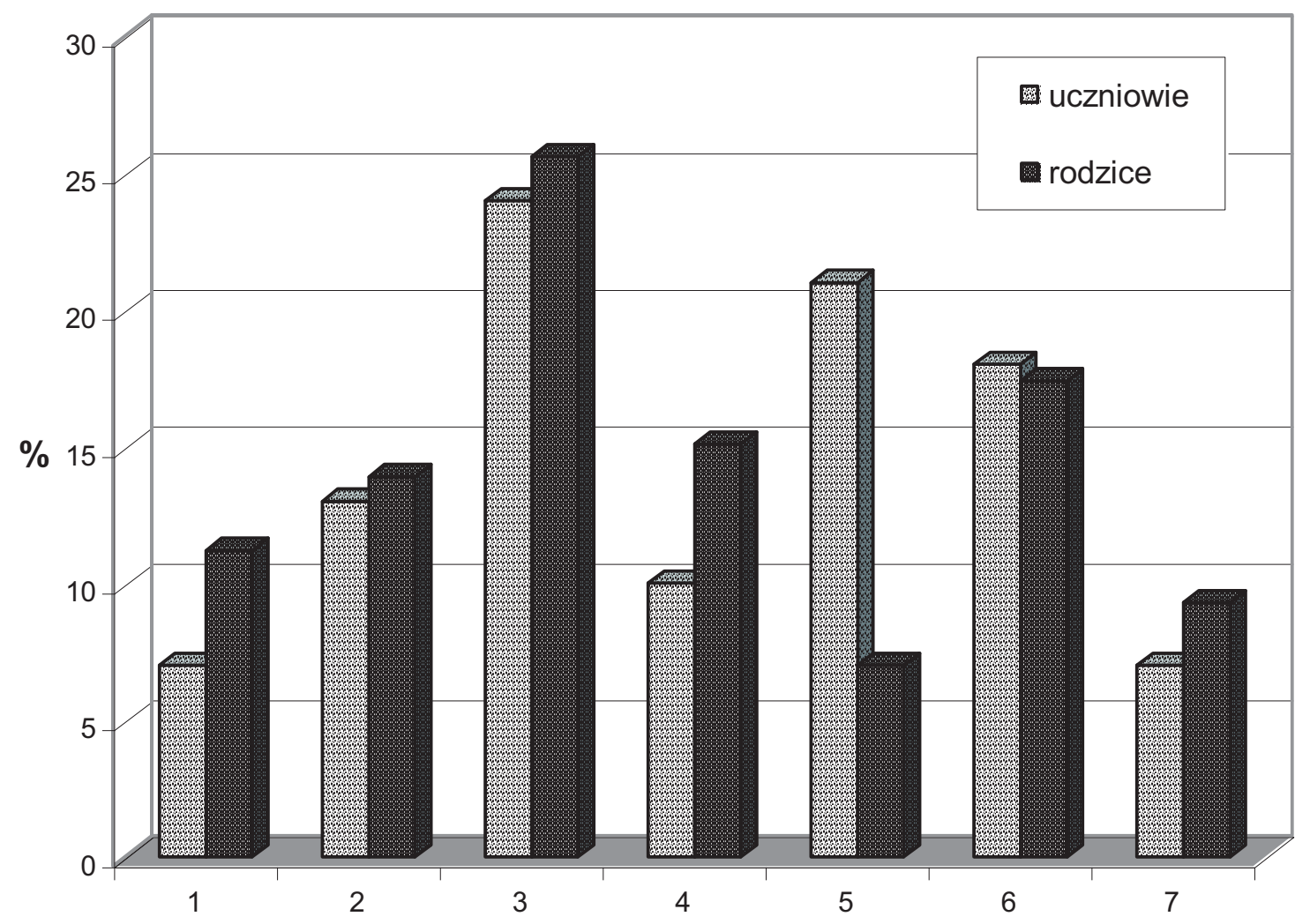

1. Istota funkcjonowania gospodarki. 2. Komunikacja interpersonalna. 3. Praca. 4. Przedsiębiorstwo. 5. Pieniądz i bankowość. 6. Podatki i ubezpieczenia. 7. Współpraca międzynarodowa.

Również rodziców zapytano o treści nauczania z podstaw przedsiębiorczości najbardziej potrzebne w dorosłym życiu. Według $26 \%$ badanych są to tematy dotyczące pracy. Dla znacznej część ankietowanych rodziców równie ważne są zagadnienia dotyczące prowadzenia własnej firmy oraz podatków i ubezpieczeń.

Podstawa programowa wyznaczyła szkołom 5 zadań, które powinny być realizowane podczas realizacji przedmiotu podstawy przedsiębiorczości. (ryc. 4). Uczniowie stwierdzili, że wszystkie zadania są ważne w przygotowaniu ich do dalszego życia, jednak najbardziej potrzebna jest im pomoc w wyborze dalszego kształcenia (25\%) oraz rozwijaniu umiejętności samokształcenia i samodoskonalenia, jak również przygotowanie ich do prowadzenia działalności gospodarczej (24\%). Najmniej, bo $10 \%$ badanych twierdzi, że szkoła powinna sprzyjać atmosferze współpracy z przedstawicielami życia gospodarczego w regionie. Natomiast większość ankietowanych rodziców uważa, że najważniejszym zadaniem szkoły jest zapewnienie możliwości uzyskania wiedzy, umiejętności i kształtowanie postaw przedsiębiorczych warunkujących aktywne uczestnictwo w życiu gospodarczym.

Chcąc przygotować młodego człowieka do aktywnego udziału w życiu społecznogospodarczym musimy nauczyć go poszukiwać, odkrywać i osiągać cele życiowe, wartości 
istotne dla odnalezienia własnego miejsca w świecie, rozwijać sprawność umysłową oraz osobiste zainteresowania, należy ukierunkowywać go na poszukiwanie prawdy oraz umiejętne dokonywanie wyborów i hierarchizacji wartości.

Ryc. 4. Najważniejsze zadania szkoły w przygotowaniu uczniów do dorosłego życia według badań ankietowych przeprowadzonych wśród licealistów

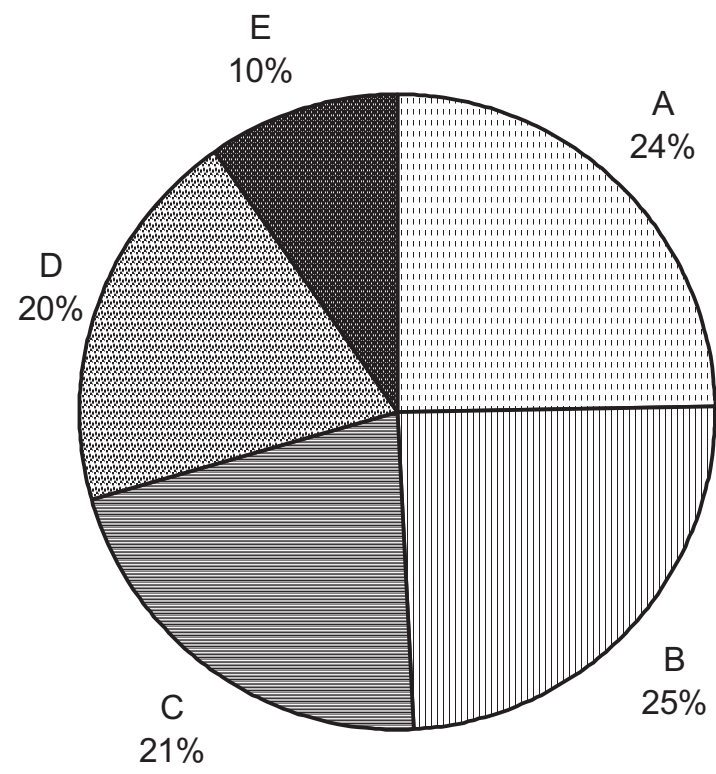

A - $\quad$ Wspomaganie uczniów w wyborze kierunku kształcenia.

B - $\quad$ Pomoc w rozwijaniu umiejetności samokształcenia i samodoskonalenia oraz indywidualnych zainteresowań prowadzeniem działalności gospodarczej.

C - $\quad$ Umożliwienie poznania specyfiki lokalnego rynku pracy

D - $\quad$ Zapewnienie możliwości uzyskania wiedzy, umiejętności i kształtowania postaw przedsiębiorczych, warunkujących aktywne uczestnictwo w życiu gospodarczym.

E - $\quad$ Tworzenie sprzyjającej atmosfery dla współpracy szkoły z przedstawicielami życia gospodarczego w regionie.

Uczniowie stwierdzili, że podczas zajęć mają możliwość:

- prowadzić dyskusje, polemizować - 29,2\%,

- rozwiązywać problemy $-22,9 \%$,

- formułować wnioski - 19,8\%,

- a ponadto mogą samodzielnie referować zagadnienia oraz wyszukiwać informacje.

Do realizacji powyższych zadań potrzebne są odpowiednie narzędzia. Licealiści zdobywając wiedzę i umiejętności z przedmiotu mogą korzystać z wielu środków dydaktycznych.

Ryc. 5 przedstawia udział poszczególnych środków dydaktycznych wykorzystywanych przez uczniów. Przykładowo, aż 100\% badanych uczniów V LO stosuje Internet w zdobywaniu wiedzy, wszyscy ankietowani w Publicznym Salezjańskim Liceum Ogólnokształcącym korzystają z podręczników, natomiast młodzież z XXX LO najczęściej sięga po środki przekazu multimedialnego, czyli filmy video oraz ogląda programy telewizyjne o tematyce ekonomicznej i gospodarczej.

Najmniej młodzieży zdobywa wiedzę wykorzystując akty prawne, uchwały, rozporządzenia oraz roczniki statystyczne. 
Ryc. 5. Wybrane środki dydaktyczne w kształceniu przedsiębiorczości - opinie uczniów

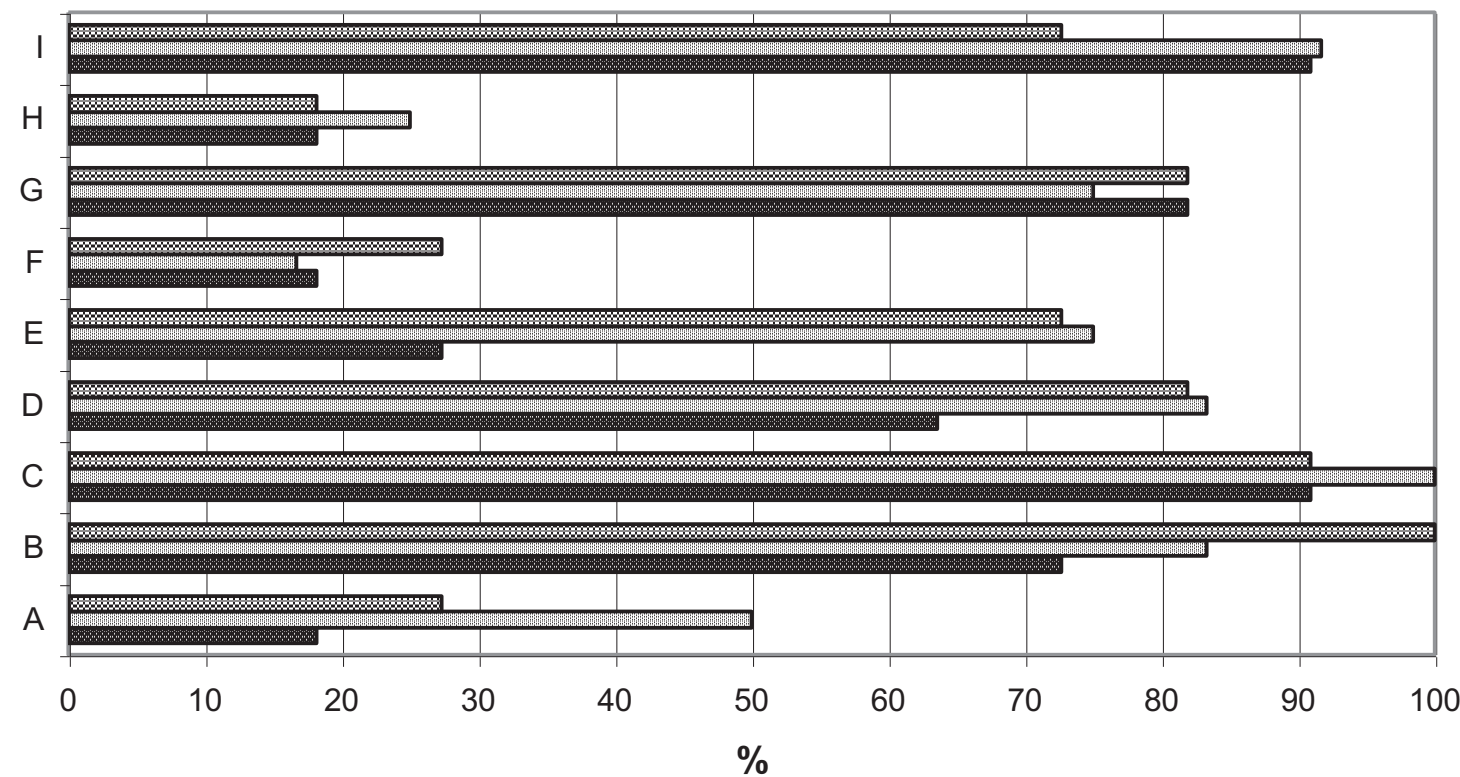

a $\vee$ Liceum Ogólnokształcące

口 Publiczne Salezjańskie Liceum Ogólnokształcące

XXX Liceum Ogólnokształcące

A - telewizja, filmy video, płyty DVD; B - ustawy, rozporządzenia, akty prawne; C - gazety i czasopisna, np. Profit, Business Week Polska in. ; D - roczniki statystyczne; E - słowniki; F - encyklopedie; G - podręczniki; H - Internet; I - programy multimedialne.

Obecnie, w celu rozwijania różnych kompetencji ucznia odchodzi się od nauczania encyklopedycznego, dlatego należy zmieniać metody nauczania. Koniecznością staje się stosowanie metod aktywizujących. Uczniowie na lekcjach muszą nauczyć się otwartej dyskusji, analizowania i wyciągania wniosków. Bardzo ważne w procesie dydaktycznym jest wdrażanie do samokształcenia. 
Ryc. 6. Opinie uczniów na temat najbardziej efektywnych metod i form kształcenia wykorzystywanych na lekcjach przesiębiorczości

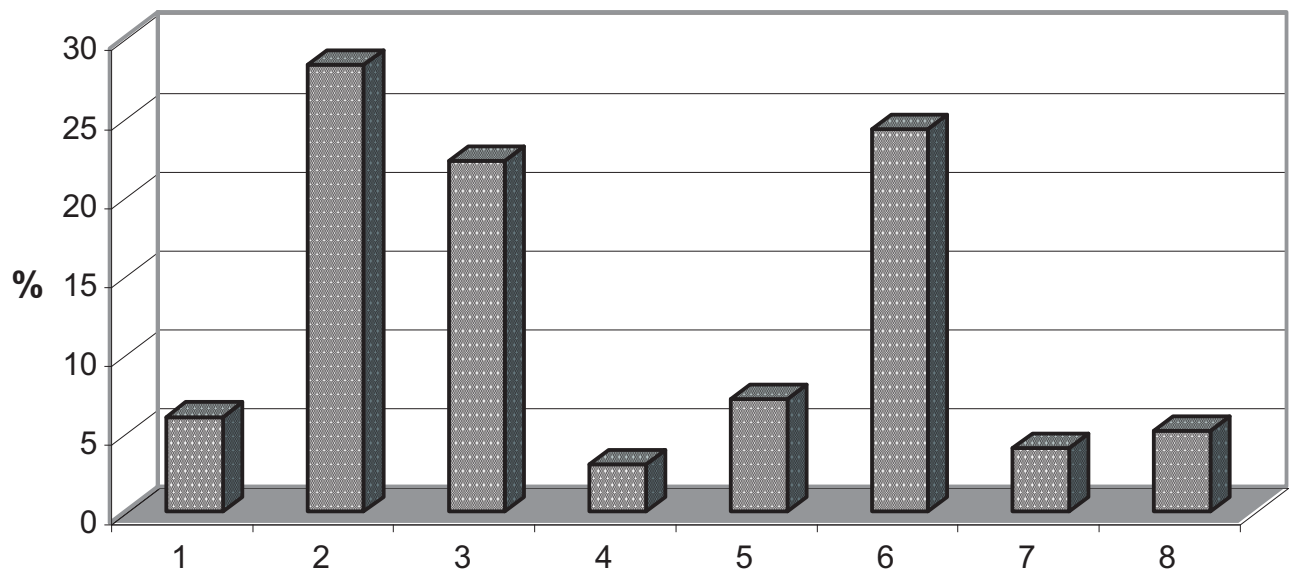

1 - wykład; 2 - wspólna dyskusja; 3 - praca w grupie; 4 - praca z tekstem ;5 - metaplan; 6 - wycieczka; 7 - metoda projektów; 8 - metoda inscenizacyjna.

Wybierając najbardziej efektywne metody nauczania (ryc. 6) uczniowie najchętniej chcieliby, aby na lekcjach stosować metody aktywizujące typu dyskusja. Na zadane pytanie, czy na lekcjach z podstaw przedsiębiorczości mają możliwość wyrażania sądów o problemach i zjawiskach społeczno-gospodarczych ponad 91\% odpowiedziała, że „tak” lub „,raczej tak". Zdecydowanie mniej osób chciałoby na lekcjach wykonywać metaplan, czy prezentować dane zagadnienie metodą projektu bądź metodą inscenizacyjną. Znacznie częściej młodzieży podoba się forma pracy w grupach. Pracując w zespołach uczniowie zobowiązani są do przestrzegania reguł takiej współpracy, dlatego najlepiej wcześniej sformułować kontrakt $\mathrm{z}$ uczniami. Ankietowani licealiści uważają, że wycieczki dydaktyczne w formie ćwiczeń terenowych dają bardzo dobre efekty w postaci szybkiego przyswajania wiedzy i zdobywania stosownych umiejętności.

Bardzo ważną rolę w procesie dydaktycznym musi odgrywać nauczyciel. To on powinien pobudzać swoich uczniów do twórczych zachowań oraz inspirować ich do działań. Nauczyciel powinien być wzorem dla młodzieży pod każdym względem - wyglądu, osobowości, poziomu wiedzy, powinien być przyjacielem i doradcą.

Rycina 7 przedstawia najistotniejsze cechy nauczyciela według opinii uczniów i rodziców: $20 \%$ objętych badaniem uczniów uważa, że powinna to być osoba lubiąca młodzież, dla znacznej części nauczyciel ma być kreatywny, czyli twórczy i pomysłowy; $15 \%$ ceni u swoich pedagogów odpowiednie zdolności pedagogiczne. Rodzice natomiast sądzą, że najważniejsza jest u nauczyciela odpowiednia wiedza merytoryczna $(37,7 \%)$ oraz zdolności pedagogiczne $(28,3 \%)$.

Głównym celem nauczania przedmiotu podstawy przedsiębiorczości jest przygotowanie młodego człowieka do aktywnego i świadomego uczestnictwa w życiu gospodarczym. Uczniowie powinni przygotować się do wyzwań, jakie stawia przed nimi współczesność.

Większość uczniów w otwartym pytaniu o cele edukacyjne, jakie stoją przed tym przedmiotem odpowiedziała:

- przygotowanie do dalszego dorosłego i aktywnego życia,

- rozwijanie umiejętności wejścia na rynek pracy,

- kształtowanie postaw przedsiębiorczych,

- poznanie funkcjonowania gospodarki Polski na tle świata. 
Ryc. 7. Nauczyciel podstaw przedsiębiorczości w opinii uczniów i rodziców

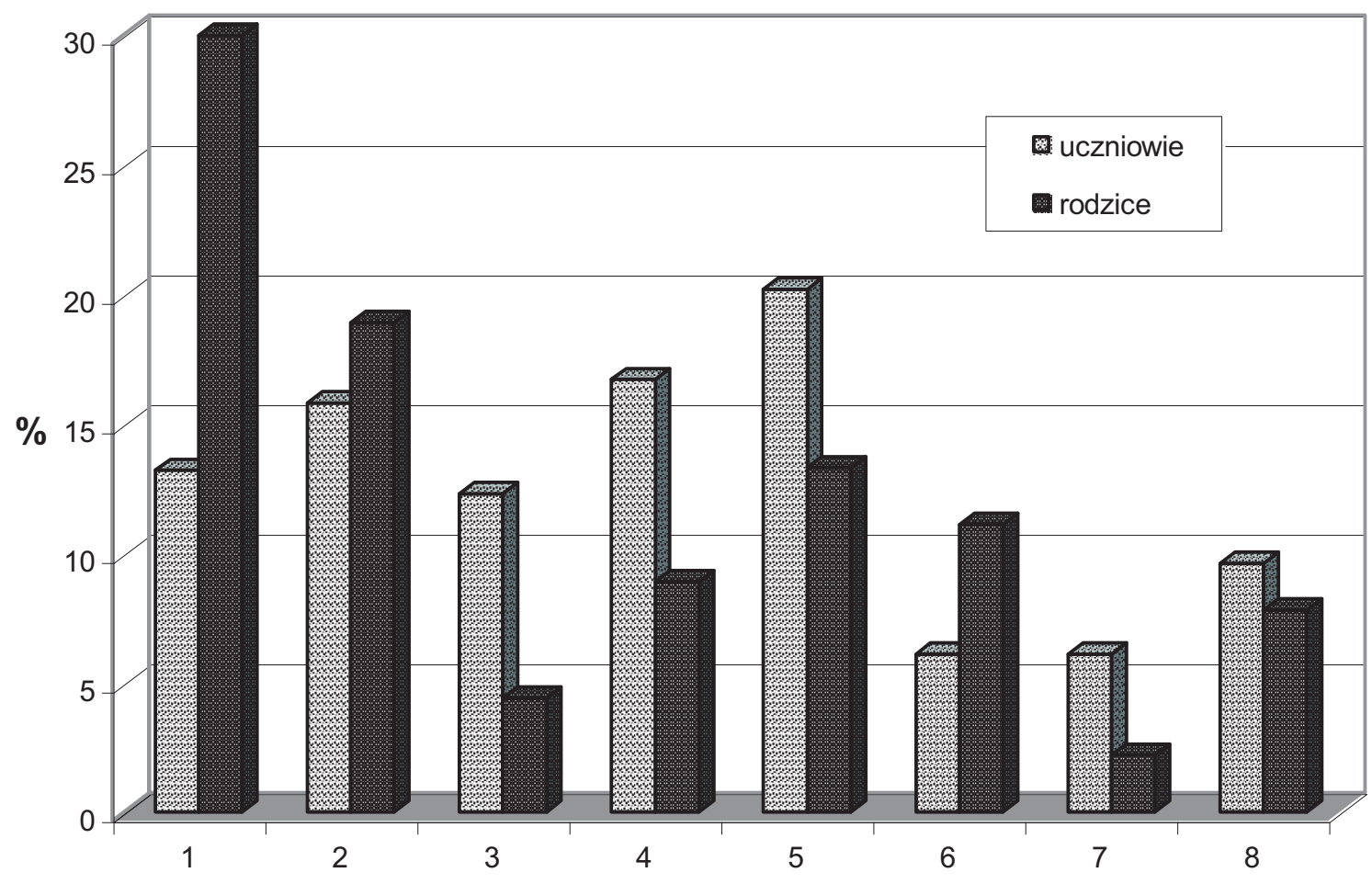

1. posiadający wiedzę merytoryczną; 2. mający zdolności pedagogiczne; 3 . dobry organizator; 4. kreatywny; 5. lubiacy młodzież; 6. aktywizujący uczniów; 7. kulturalny w sposobie bycia; 8. posiadający autorytet

Według części ankietowanych uczniów przedmiot ten ma „stworzyć ludzi wykształconych, światłych, przedsiębiorczych i operatywnych” takich, którzy „poradzą sobie w życiu”. Podobnych odpowiedzi udzielili rodzice, którzy uważają za główne cele edukacyjne:

- kształtowanie umiejętności potrzebnych w życiu społeczno-gospodarczym,

- kształtowanie postaw przedsiębiorczych,

- pomoc w wyborze dalszego kierunku kształcenia,

- wprowadzenie na rynek pracy,

- zrozumienie funkcjonowania gospodarki rynkowej,

- rozwijanie samodoskonalenia i samokształcenia.

Z przeprowadzonych badań wynika, że przedmiot podstawy przedsiębiorczości spełnia oczekiwania większości ankietowanych uczniów i rodziców. Wykształcenie młodych ludzi, którzy będą potrafili odnaleźć się w szybko zmieniających się procesach zachodzących w gospodarce rynkowej, wydaje się zadaniem bardzo ambitnym, które stoi przed dzisiejsza szkołą i jej nauczycielami.

\section{LITERATURA}

Makieła Z., Rachwał T., 2002, Podstawy przedsiębiorczości, Wydawnictwo Nowa Era, Warszawa.

Makieła Z., 2004, Nowy przedmiot nauczani dla geografów - podstawy przedsiębiorczości [w:] Kształcenie i doskonalenie nauczycieli geografii w Polsce i w krajach Unii Europejskiej w drodze do jednoczącej się Europy, Wydawnictwo Naukowe Akademii Pedagogicznej, Kraków. 
Rachwał T., 2004, Ksztaltowanie postaw przedsiębiorczości u uczniów - wyzwaniem dla nauczycieli geografii [w:] Kształcenie i doskonalenie nauczycieli geografii w Polsce i w krajach Unii Europejskiej w drodze do jednoczącej się Europy, Wydawnictwo Naukowe Akademii Pedagogicznej, Kraków.

Rozporządzenie Ministra Edukacji Narodowej i Sportu z dnia 26 lutego 2002 r. w sprawie podstawy programowej wychowania przedszkolnego, kształcenia ogólnego w poszczególnych typach szkół, Dz. U. z 2002 Nr 51, poz. 458. 